Click www.researchjournal.co.in/online/subdetail.html to purchase.

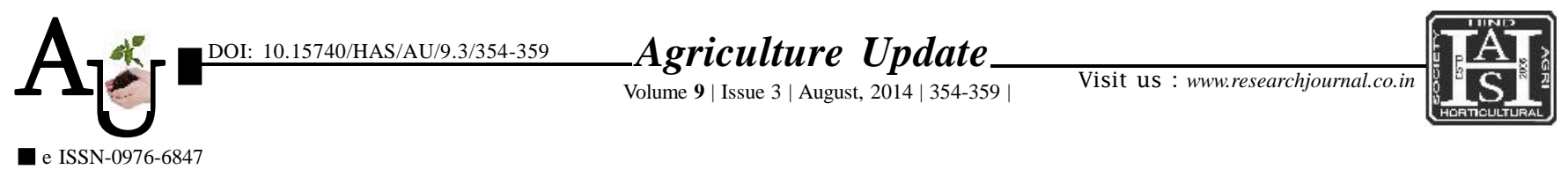

\title{
Research Article \\ Assessments of training need of sweet orange growers in Marathwada region
}

\author{
R.P. KADAM, S.M. UMATE, G.S. PAWAR AND O.R. WAGHMARE
}

Article Chronicle : Received :

01.06.2014;

Revised :

13.06.2014;

Accepted :

28.06.2014

KeY Words:

Sweet orange growers,

Training need
SUMMARY : Present study was purposively conducted in Nanded districts because this district occupies highest area under sweet orange. The district consist 16 talukas, out of that Bhokar and Nanded taluka was chosen purposively based on maximum area under cultivation. Six villages from each taluka were selected thus, total 12 village were selected from the talukas. The respondents were selected those having he sweet orange garden of at least 5 years old. From each village 10 sweet orange growers were selected randomly. Near about half of the respondent $(45.84 \%)$ were educated upto primary education, with $(40.90 \%)$ of semi-medium land holding, 83.33 per cent had medium annual income, 65.83 per cent had medium economic motivation, respondents 60.00 per cent had medium social participation, 72.50 per cent had medium extension contact, 63.34 per cent were in medium category of use of sources of information, 72.50 per cent had medium risk preference, respondents 74.16 per cent had medium market orientation, $(63.34 \%$ ) had medium farming experience, 66.66 per cent were having the orchard of 11-15 years old age, 63.33 per cent found in medium level of training needs. This might be due to satisfactory level of knowledge and skill of the respondents about sweet orange plantation. extension contact, land holding, annual income, risk preference, economic motivation social participation and market orientation this variables had positive but non-significant relationship with training need.

How to cite this article : Kadam, R.P., Umate, S.M., Pawar, G.S. and Waghmare, O.R. (2014). Assessments of training need of sweet orange growers in Marathwada region. Agric. Update, 9(3): 354-359.
Author for correspondence :

\section{R.P. KADAM}

Department of Extension Education, Vasantrao Naik Marathwada Krishi Vidyapeeth, PARBHANI (M.S.) INDIA

See end of the article for authors' affiliations 